\title{
HUMANITARIAN DEMINING IN UKRAINE: THE PROBLEM OF TERMINOLOGY TRANSLATION
}

\section{Palchevska O. S.}

\section{INTRODUCTION}

Terminology can be interpreted in three different ways: glossary of terms, terminology science and practice. As term is defined as a linguistic unit that designates a concept belonging to a given subject field, it was concluded that the formal side could be examined with linguistic methods.

In times of relative peace, the process of mine removal is referred to as humanitarian demining. This is a thorough, time-intensive process that seeks to locate any and all mines so that the land or sea area may be safely returned to normal use. It is vital that this process be exhaustive. In this context demining is one of the tools of mine action. Coordinated by Mine Action Coordination Centers run by the United Nations or a host government, civilian mine clearance agencies are tasked with the demining. In post-conflict areas, minefields are often contaminated with a mixture of explosive remnants of war (ERW) that includes unexploded ordnance as well as landmines. In that context, the humanitarian clearance effort is often referred to as battle area clearance. The Geneva International Centre for Humanitarian Demining (hereinafter referred to as GICHD) sends its experts to the governmental and nongovernmental organizations in Ukraine in order to make their valuable contribution to the implementation of the projects aimed at reduction of mines and explosive remnants of war impact in the Eastern Ukraine. In terms of support to mine action in Ukraine, GICHD conducted a serials of training courses for translators, interpreters and language assistants on the proper use of English technical terminology in the context of humanitarian demining. Being the participants of one of the mentioned trainings, we analyzed the peculiarities of communication in the context of humanitarian demining, identified so-called "white spots" and problem areas, and, accordingly, set the main tasks that Ukrainian interpreters and linguists face in this area. Thus, the purpose of this article is to analyze the features of communication, terminology and lexicography in the sphere of Humanitarian Demining. First of all, it should be noted that the vocabulary of humanitarian demining is a virtually new area for Ukraine both in the context of translation and in the context of theoretical terminological research.The research makes an attempt to divide and analyze the collected information in three problem blocks: communication problems 
that arise when the information is rendered from English-speaking to Ukrainianspeaking participants of the humanitarian demining process; collection and linguistic analysis of mine clearance vocabulary; creation of explosives and demining devices complex bilingual dictionary.

\section{Theoretical bases for terminology translation}

Terminologies are playing an increasing role in the society of today. The combination of an accelerated rate of information production and the increase in speed at which information travels has many consequences, and raises many issues. If we humans are to both produce and consume more information in less time while maintaining or even improving the content quality, we need all the help we can get. For specialized domains, using the correct terminology plays a major part in efficient communication. Creating and maintaining a terminology however, has been, and still is, a time consuming activity. A terminology contains definitions of domain-specific concepts and the terms which represent these concepts. A terminology also contains information on how the different concepts are related to each other. Having a common terminology within a subject field, together with tools that integrate the terminology with e.g. document authoring activities, can, among other things, reduce the number of possible communication errors. Terminology Work (TW) (analyzing terminology and creating a terminology), terminography (publishing terminology reference works), and terminology management are all tasks within the field of terminology which have traditionally been performed without the aid of computers. All tasks involve dealing with relatively large data sets with complex dependencies and relationships. For example, to create and publish a domain-specific terminology, terminologists would manually extract possible terms, i.e. term candidates, either by analyzing domain-specific literature or by interviewing domain experts. The relations between term candidates would then be disseminated, and where necessary the terminologist would consult domain experts. Finally, the terms are structured into defined concepts which are then published as a work of reference.

The term terminology is ironically an ambiguous term, and can represent three separate concepts. Terminology can either refer to 1) "Terminology science, [the] interdisciplinary field of knowledge dealing with concepts and their representations", 2) an "aggregate of terms which represent the system of concepts of an individual subject field", or 3) a "publication in which the system of concepts of a subject field is represented by terms" ${ }^{1}$. Analyzing, defining and naming concepts is referred to as terminology work and publishing

${ }^{1}$ Felber H. Terminology manual. Available online http: //unesdoc.unesco.org/Ulis/ cgi- bin/ulis.pl?catno=62033, Paris 1984 . 
the results of this work is referred to as terminography. The field of terminology (Terminology Science) is a polymethodological and polytheoretical field, and methods and theories tend to differ between practitioners in different countries. Ongoing work is however being done at the International Organization for Standardization (ISO), specifically within ISO Technical Committee (ISO/TC 37)1, aimed at providing a common standard related to terminology work. The ISO history behind the creation of the ISO terminology standards originate from Eugene Wüster's work and the so called Vienna school of terminology ${ }^{2}$. In her article on scientific and technical translation in the second edition of the Routledge Encyclopedia of Translation Studies" ${ }^{3}$, claims that “[t]he binominal phrase 'science and technology' occurs frequently in corpora of news and academic prose [...] and it is perhaps its familiar nature which leads us very readily to use the term 'scientific and technical translation'." What Olohan is concerned with here is whether these two terms can really be grouped together in any meaningful way when referring to a particular field of translation. Byrne ${ }^{4}$ seems to be sceptical with regard to this issue since he draws a clear distinction between scientific translation and technical translation, using Pinchuck's ${ }^{5}$ three key categories of information that provide the material for STT:

1 . The results of basic or pure science.

2. The results of applied scientific research geared toward solving particular problems.

3. The work of technologists, which is intended to create marketable industrial products or processes.

Before discussing the issue of scientific and technical translation or scientific vs. technical translation, let us first consider some definitions of the terms science and technology. Oxford Dictionaries Online defines science as "the intellectual and practical activity encompassing the systematic study of the structure and behaviour of the physical and natural world through observation and experiment", while technology is defined as "the application of scientific

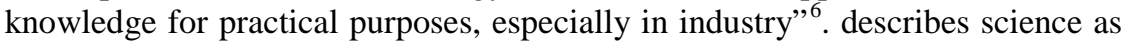

2 Felber H. Terminology manual. Available online http: //unesdoc.unesco.org/Ulis/ cgi- bin/ulis.pl?catno=62033, Paris, 1984.

${ }^{3}$ Olohan M. Scientific and Technical Translation, in: Baker, Mona; Saldanha, Gabriela (eds): Routledge Encyclopedia of Translation Studies, London/New York 2009, P. 246-249.

${ }^{4}$ Byrne J. Scientific and Technical Translation Explained. A Nuts and Bolts Guide for Beginners, Manchester, 2012.

${ }^{5}$ Pinchuck I. Scientific and Technical Translation, London, 1977.

${ }^{6}$ Brekke M. Linguistic Aspects of the Translation of Scientific and Technical Texts, in: Kittel, Harald; Frank, Armin P.; Greiner, Norbert; Hermans, Theo; Koller, Werner; Lambert, José; Paul, Fritz (eds); in association with House, Juliane; Schultze, Brigitte: Übersetzung. Translation. Traduction. Ein internationales Handbuch zur Übersetzungsforschung. Volume 1. Berlin/New York P. 619-635, 2004. 
"an essentially open-ended effort to uncover, describe, quantify and account for the fundamental non-intentional regularities of the perceivable or cognizable universe" and technology as "an advanced form of tool-based problem solving arising at the point where a practical need or intent is illuminated by theoretical insight" (ibid.:628). Byrne ${ }^{7}$ gives a very vivid description of the distinction between science and technology with regard to translation, stating that "scientific translation relates to pure science in all of its theoretical, esoteric and cerebral glory while technical translation relates to how scientific knowledge is actually put into practical use, dirty fingernails and all." 8 makes a less colourful but equally intuitive distinction by referring to Newmark's ${ }^{9}$ comparison between the "concept-centred" language of science and the "object-centred" language of technology. However, as intuitive as this distinction may seem at a theoretical level, both Salama-Carr and Byrne note that, in reality, it is more difficult to draw a clear line between scientific and technical texts since it is common for texts to combine elements of both the scientific and the technical realm. This close interrelation between science and technology is highlighted by Brekke ${ }^{10}$, who calls technology "the 'worldly' face of science”. Also, Pinchuck $^{11}$ claims that "today's pure science may be tomorrow's technology" and indeed, it seems that there exists a symbiotic relationship between science and technology that inextricably binds the two fields together. For example, as Pinchuck (ibid.) points out, Faraday's experiments were initially prompted by sheer curiosity but eventually laid the foundations for the industrial application of electrical energy.

Looking at the issue from another angle, most of today's scientific experiments cannot be envisaged without the help of technical appliances, such as telescopes and microscopes, which extend our epistemological capacities of basic-level perception and manipulation ${ }^{12}$. So, when Byrne ${ }^{13}$ (2012:2) claims

${ }^{7}$ Byrne J. Technical Translation. Usability Strategies for Translating Technical Documentation, Dordrecht, 2006.

${ }^{8}$ Salama-Carr M. The Translation of Scientific Discourse - Constraints and Challenges, in: Krein-Kühle, Monika; Wienen, Ursula; Krüger, Ralph (eds): Kölner Konferenz zur Fachtextübersetzung (2010), Frankfurt/M. P. 19-32. 2013.

${ }^{9}$ Newmark P. Approaches to Translation, London 1981.

${ }^{10}$ Brekke M. Linguistic Aspects of the Translation of Scientific and Technical Texts, in: Kittel, Harald; Frank, Armin P.; Greiner, Norbert; Hermans, Theo; Koller, Werner; Lambert, José; Paul, Fritz (eds); in association with House, Juliane; Schultze, Brigitte: Übersetzung. Translation. Traduction. Ein internationales Handbuch zur Übersetzungsforschung. Volume 1. Berlin/New York P. 619-635 2004.

${ }^{11}$ Pinchuck I. Scientific and Technical Translation, London 1977.

${ }^{12}$ Lakoff G. Women, Fire, and Dangerous Things. What Categories Reveal About the Mind, Chicago 1987.

${ }^{13}$ Byrne J. Scientific and Technical Translation Explained. A Nuts and Bolts Guide for Beginners, Manchester 2012. 
that technical texts are "designed to convey information as clearly and efficiently as possible", while scientific texts "will discuss, analyze and synthesize information with a view to explaining ideas, proposing new theories or evaluating methods", he may in fact be describing a continuum, with science and technology as the two endpoints and applied science covering the middle ground. While keeping in mind this general distinction between science and technology, the symbiotic relationship between the two fields and the hybrid nature of many scientific and technical texts encountered in the real world seem to justify the joint use of the two terms in the designation scientific and technical translation.

However, a distinction that should be made for the sake of clarity is that between technical translation and specialized translation. Olohan ${ }^{14}$ notes that the term technical translation is often used to refer to the translation of texts outside the fields of science and technology and that some scholars see technical translation as a synonym for specialized translation. In the same context, Byrne ${ }^{15}$ (2006:3) criticizes the tendency to subsume LSP texts from the fields of law, finance or economy under the label technical translation. The problem, as Byrne rightly points out, is that "[s]imply because a field or subject area has unique or specialised terminology does not make it technical". For the purpose of the present thesis and in line with Borja et al. ${ }^{16}$, I understand specialized translation as the translation of texts that serve practical rather than aesthetic purposes. After all, when dealing with texts that can clearly be assigned to one of the two fields, we can still resort to the more specific designations scientific translation or technical translation.

Specialized translation can thus be seen as a cover term for various more specific modes of translation, such as legal translation, financial translation and also STT, while scientific and technical translation is to be understood in the narrower sense discussed above.

As researchers working in the field of scientific and technical translation often point out, this huge significance of STT both at a societal level and at the level of individual translation practice stands in sharp contrast to the scarcity of translational research carried out in this field. Traditionally, STT has been considered as easier or as more straightforward than literary translation due to the "perceived universality of the language of science and/or of scientific

${ }^{14}$ Olohan M. Scientific and Technical Translation, in: Baker, Mona; Saldanha, Gabriela (eds): Routledge Encyclopedia of Translation Studies, London/New York 2009, P. 246-249.

15 Byrne J. Technical Translation. Usability Strategies for Translating Technical Documentation, Dordrecht 2006.

${ }^{16}$ Borja A., Garcia I., Montalt V. Research Methodology in Specialized Genres for Translation Purposes, in: Mason, Ian (ed.): The Interpreter and Translator Trainer 3(1), Special Issue: Training for Doctoral Research, Manchester P. 57-77, 2009. 
thought" ${ }^{17}$. and due to the apparent absence of linguistic or conceptual creativity in this field of translation. Scientific and technical translation, together with specialized translation in general, has therefore often been reduced to a simple, almost automatic transcoding process. Some scholars, such as Mounin ${ }^{18}$, went so far as to claim that scientific translation could eventually be completely automated (see also Arntz 2001:172) ${ }^{19}$. This derogatory view of STT and specialized translation in general has a long tradition that can be traced back to Friedrich Schleiermacher. What is also interesting is Schleiermacher's justification for his disparaging view of commercial translation. What is striking with regard to this quote is that, if we disregard his remark on "negotiations", Schleiermacher's description seems to be readily applicable to technology and science, the former dealing with well-defined objects and the latter trying to uncover and to describe regularities in the world, often by resorting to measurements or arithmetical or geometrical operations. Therefore, it seems that Schleiermacher's criticism of commercial translation can also be interpreted as a criticism of STT.

The linguistic analysis was based on the two-foldedness of the term, so we took into consideration that terms had a conceptual and a linguistic side, and the linguistic form itself was composed of two parts: a base and a modificator. We only dealt with linguistic characteristics that might be relevant for terminology and translation, for terminology management and for term identification. Accordingly, the formal side was examined from a morphologic, syntactic, lexical and semantic point of view, as for the conceptual side the central element of the term structure (the base) was identified.

In the linguistic examination a distinction was made between the analysis of the complete terminological units (term forms, semantic and syntactic analysis) and the analysis of the individual lexical items (lexical units, word classes, word formation mechanisms). The analysis of the complete terminological units took place with the help of syntax, semantics and terminology, which was accompanied by the analysis of the individual lexical constituents by means of morphology and lexicology.

Each linguistic analysis started with the classification of the terminological units according to their structures, based on which we differentiated between simple, complex and short form terms. The collection of the equivalents and the term variants made it possible to examine terminological synonymy, i.e. how many concepts are designated with more

${ }^{17}$ Olohan M. Scientific and Technical Translation, in: Baker, Mona; Saldanha, Gabriela (eds): Routledge Encyclopedia of Translation Studies, London/New York 2009. P. 246-249.

${ }^{18}$ Mounin G. Die Übersetzung. Geschichte, Theorie, Anwendung, München, 1967.

${ }_{19}$ Arntz R. Fachbezogene Mehrsprachigkeit in Recht und Technik, London/New York. P. 43-63, 2001. 
than one term. The study of the relations between the term variants lead us to the distinction of four major (and 12 minor) groups: the variants were formed by short forms, lexical modification, structural modification and borrowing.

The comparison of the terminological forms pointed out the presence of polysemy. This phenomenon is an important issue in the translation-oriented terminology since the starting point is the linguistic form appearing in a text; it is thus essential to determine which meaning of the term we are dealing with.

As we saw every term as a structure composed of a base and a modificator we could distinguish four different groups according to the linguistic forms of the terminological units: complex terms, compounds, simple terms and short forms (acronyms and abbreviations).

Within the framework of the syntactic analysis we examined how many lexical units the terms were composed of, and we described the most frequent structures.

From a lexical point of view the number of the terminological entries (concepts), the number of the terms, the total number of the lexical units and the number of the individual units were determined. The first 15 most frequent nouns and the first 10 most frequent adjectives were identified. In the case of the individual lexical items a word class classification was carried out.

In the morphological part, firstly the affixes were identified: the nominal and adjectival prefixes and suffixes occurring in the individual lexical items, and then the compounds were analyzed from a structural point of view.

\section{Humanitarian demining and translation}

The OSCE Project Co-ordinator in Ukraine is directly involved in humanitarian demining ${ }^{20}$.

The terminological system of humanitarian demining has not yet been the subject of research of Ukrainian scientists, although an attempt has been made to analyze some nominations in the context of military terminology and translation studies A. T. Aksenov, V. V. Balabin, Ye. A. Yelina, V. M. Lisovskyi,
I. M. Matiushyn,
L. L. Neliubin,
R. Kh. Salimova,
O. O. Chernyshov, V. N. Shevchuk, N. D. Fomina.

According to the international requirements, the official language of humanitarian demining in Ukraine is English, which can create problems in transferring information to Ukrainian demining specialists.

In the framework of further support for mine action programs in Ukraine, GICHD (Geneva International Center for Humanitarian Demining) conducted

${ }^{20}$ Мартинюк Віталій, Зварич Олена. Гуманітарне розмінування Донбасу - довгий шлях до безпеки людей. УНЦПД, 22 рік видання, №30/753, 30 квітня 2016. Available online URL: http://www.ucipr.org.ua/index.php?option=com_content\&view=article\&id=91:guman-tarnerozm-nuvannya-donbasu-dovgiy-shlyah-do-bezpeki-lyudey\&catid=8\&lang=ua\&Itemid=201. 
two training courses on the preparation of translators for the use of English technical terminology in the context of humanitarian demining. The course was developed by GICHD in co-operation with the Danish Refugee Council / Danish Mine Action Group (DRC / DDG) and was first implemented in January 2017 as a pilot project. The aim of this course was to improve the ability of local governmental and non-governmental organizations to participate in training and consultive missions, and also in creating the expert interpreters group with knowledge of specialized terminology within the relevant organizations framework. The training was focused on the correct use of English-language technical terminology in the context of humanitarian demining.

Because of the participation in one of the mentioned trainings, we analyzed the peculiarities of communication in the context of humanitarian demining, identified the so-called "white spots" and problem areas, and, accordingly, we set the main tasks that are addressed to Ukrainian translators and linguists in this area. Thus, the purpose of this investigation is the attempt to explore the features of communication, terminology and lexicography in the framework of humanitarian demining.

First of all, it should be noted that the vocabulary of humanitarian demining is practically a new area for Ukraine both in the context of translation and in the context of theoretical terminological exploration. Accordingly, the research task is an attempt to divide and analyze our collected information in the direction of three conditional problem blocks:

- communication problems that arise from the transfer of information from English-speaking to Ukrainian-speaking participants humanitarian demining of the process;

- collection and linguistic analysis of the demining terms;

- creation of complex bilingual dictionary of explosive devices.

There are significant differences in the NATO and former USSR ammunition classification systems that cause misunderstandings during interpreting or translation of documents. As a consequence, different categories of munition process use different classifications. The occupational titles in the demining groups of NATO countries and the former USSR also differ, as well as the number of participants in the group (which may lead to wrong perceptions of orders and commands). Very often, translators who are involved in the humanitarian demining process are not demining specialists and do not have basic knowledge in this area, and demining specialists who sometimes perform interpreting functions do not have sufficient English language proficiency, which can lead to serious communication errors.

The peculiarity of the terminological sphere of humanitarian demining is that it lies on the border of military terminology and terminology of emergency situations. Such a terminological system as the terminology of other high-tech 
fields of science and technology can be regarded as developing very dynamically. Many linguistic and extra-linguistic factors influence this. For example, the same nominations can appear in both terminological systems with different shades of meaning.

When processing and standardizing the terms of humanitarian demining and their subsequent translation, the following factors, which cause problems and misunderstandings, should be taken into account.

For example, the mix of demining terms and the mining theory terms should be avoided. In the context of this remark, we propose to consider a key nomination for the English language term. According to Oxford English Dictionary included in ABBYY Lingvo $\mathrm{x} 5$ in the form of a noun, the nomination has several values (including nomadic ones):

1) an excavation in the earth for extracting coal or other minerals a copper mine

[in sing.] an abundant source of something, especially information the text is a mine of information for biographers and historians;

2) a type of bomb placed on or just below the surface of the ground or in the water, which detonates on contact with a person, vehicle, or ship

a subterranean passage under the wall of a besieged fortress, especially one in which explosives were placed to blow up fortifications ${ }^{21}$.

The British Free Library Encyclopedia has got 2416 articles with the "mine" component, where the semantics corresponds to either the first or second LSV ${ }^{22}$. Here are examples of fragments of some of them.

Mine (weapon) Mine, in military and naval operations, a usually stationary explosive device that is designed to destroy personnel, ships, or vehicles when the latter come in contact with it. Submarine mines have been in use since the mid-19th century; land mines did not become a significant factor in warfare until a hundred years later. https://www.britannica.com/technology/ mine-weapon

King Solomon\&apos;s Mines novel by Haggard

King Solomon's Mines, novel by H. Rider Haggard, published in 1885. One of the first African adventure stories, it concerns the efforts of a group of Englishmen to find the legendary diamond mines of King Solomon. https://www.britannica.com/topic/King-Solomons-Mines-novel-by-Haggard

Chile mine rescue of 2010

Chile mine rescue of 2010, also called Chile mining accident of 2010, rescue of 33 workers from the San Jose gold and copper mine on October 13,

\footnotetext{
${ }^{21}$ ABBYY Lingvo x5. URL: Available online https://www.abbyy.com/ru-ru/support/lingvox5_sr/.

${ }^{22}$ Encyclopedia Britannica. URL: Available online https://www.britannica.com/ search?query=mine.
} 
2010, 69 days after the mine's collapse on August 5. https://www.britannica. com/event/Chile-mine-rescue-of-2010.

Thus, when the first and second fragments contain clear linguistic and extralinguistic markers of the "mine" (weapon) type which point to the semantics of the nomination, the third part, which deals with rescue, may be problematic for a person to perceive, whose basic knowledge of the English language is not high enough.

Among the terms we studied, a significant number of full or partial borrowings from English or through English are singled out: aydum (audit); векторні дані (vector data); ГIC (GIS); детонатор (detonator); економічна ефективність (cost-effectiveness); інспекиійний орган (inspection body); інспекція (inspection); інциидент при розмінуванні (demining incident); контракт (contract) ; контрольна зона або пункт (control area or point); лічензія (licence); маркування (marking); механічні інструменти (mеchanical tools); моніторинг (monitoring); незнешкоджений елемент бомби (bomb live unit (BLU)); нейтралізувати (neutralise); операційний аналіз (OA) (operational analysis (OA)); партнер 3 імн (тre partner); пілотне випробування (pilot test); постійна система маркування (permanent marking system); постійнодіючі оперативні процедури (ПОП) (standing operating procedures (SOPS)); протокол V (protocol V); ризик, пов'язаний з мінами (mine risk); розблокування території «ленд-реліз» (land release); розмінувальна машина (demining тасhine); самонейтралізація (selfneutralisation); система екологічного менеджменту (CEM) (environmental management system (EMS); система маркування (marking system); спонсор (sponsor); стандартні оперативні прочедури (СОП) (standard operating procedures (SOPS)); форс-мажор (force тајеure).

A large number of terms is a terminology commonly used in the vocabulary or they fall into the terminology of humanitarian demining with other terminology systems. For example, let's look at the term очищення / розмінування (clearance). According to the Dictionary of the Ukrainian language, очищення, "action meaning to clean and clear": Скільки існує ремонт суден, стільки ж очищення й фарбування ланцюгів робились вручну (Worker's Newspaper, 9.I. 1962, 1); Для очищення i сортування насіння використовують усі наявні зерноочисні машини (Cereal legumes, 1956, 42); Ідеальне очищення стічної води дав змогу якнайповніме ї̈ використати (Khliborob Ukraine, 4, 1966, 27); Чекаючи гостей, король зігнав тисячі селян для очищення замка (Anton Hizhnyak, D. Galitsky, 1958, 555); Велику роботу по оздоровленню, очищенню і збагаченню намої мови провадять, звичайно, наші лексикографи (Maksym Rylskyi, III, 1956, 66) ${ }^{23}$.

\footnotetext{
${ }^{23}$ Словник украӥнської мови в 11 томах / за ред. І. К. Білодіда, Київ 1970-1980.
} 
The English nomination "clearance" has the following main LSVs:

1) the action or process of clearing or of being dispersed;

2) the removal of buildings, people, or trees from land so as to free it for alternative uses;

3) the removal of contents from a house; (in soccer and other sports) a kick or hit that sends the ball away from one\&apos;s goal;

4) the potting of all the balls remaining on the table in a single break.

Очищенн /розмінування (clearance) in the context of mine action, concerns tasks or measures for the disposal and / or destruction of all hazards associated with mines in a given area at a given depth ${ }^{24}$.

A specific problem for translation is a group of slang nominations, which often appear in the communication of demining specialists. For example:

Bone (literally bone) - AB-1 bomber B-1 (American Supersonic Strategic Bomber with variable sweep wing)

Bull Bomb (literally a bull bomb) A package intended to disperse propaganda leaflets. Recommended by user Steve Neal. Fitty - Slang for an M2 .50 caliber machine gun

Arc light (literally arc lamp) code name for B-52 bombers strikes along the Cambodian-Vietnamese border. These operations shook earth for ten miles away from the target area.

Bouncing Betty (literally jumping mine) antipersonnel mine with two charges: the first propels the explosive charge upward, and the other is set to explode at about waist level

Chicom mine (literally mines of Chinese Communists) Chinese mine; can be made of plastic

Clacker (literally rattle, rattlesnake) a small hand-held firing device for a claymore mine

Claymore (literally mine Claymore) an antipersonnel mine carried by the infantry which, when detonated, propelled small steel cubes in a 60-degree fan-shaped pattern to a maximum distance of 100 meters $^{25}$.

Creating a comprehensive bilingual dictionary of explosive devices.

Ukrainian language policy is realized in the need to create both monolingual Ukrainian terminological dictionaries and glossaries as well as bilingual lexicographic sources. Unfortunately, there is no dictionary published in Ukrainian in the field of demining. In 2014, the UN Mine Action Service (UNMAS) developed and issued the Glossary of Mine Action Definitions,

${ }^{24}$ Глосарій термінів, визначень $і$ скорочень $з$ питань протимінної діяльності. URL: Available online https://www.mineactionstandards.org/fileadmin/MAS/documents/imasinternational-standards/Ukrainian/IMAS_04.10_ukr.pdf .

${ }^{25}$ Glossary of Military Terms and Slang from the Vietnam War. URL: Available online http://www2.iath.virginia.edu/sixties/HTML_docs/Resources/Glossary/Sixties_Term_Gloss_A_C.html. 
which is kind of the activities standard ${ }^{26}$. This glossary provides a list of terms, definitions and abbreviations used in anti-mine activities. If there are two or more alternative definitions commonly used, they are all given. Glossary article looks like this:

Залишені касетні босприпаси (abandoned cluster munitions) (2009)

касетні боєприпаси або вибухонебезпечні бойові елементи касетних боєприпасів, які не були використані і були залишені чи кинуті $i$ більше не знаходяться під контролем тієї сторони, що їх залишила або викинула. Вони можуть бути підготовленими до використання або й ні. (Конвенція про касетні боєприпаси (Конвенція ССМ)).

The glossary has 43 pages and contains only basic concepts and definitions, which in our opinion is not sufficient for high-quality oral and written translation. The document is based on the English language standard IMAS 04.10 "Glossary of Mine Action Terms, Definitions and Abbreviations" ${ }^{27}$. Here is the example of the article of the glossary:

abandoned cluster munitions (2009)

cluster munitions or explosive sub-munitions that have not been used and that have been left behind or dumped, and that are no longer under the control of the party that left them behind or dumped them. They may or may not have been prepared for use. (CCM)

It can be noted that when information in the English standard is given in alphabetical order, the Ukrainian translation retains the principle of submitting the terms of the original (terms are ordered in English), which can create significant problems for the interpreter.

Russian authors S. M. Palei and T. F. Serafyna have compiled an English-Russian and Russian-English dictionary "Dictionary for the removal of explosive devices ${ }^{28}$. The dictionary was published in 2010 and includes 5000 terms. The dictionary is based on cluster principle. Amount and structure of the dictionary do not allow to contain all the necessary terms. For example, the above term abandoned cluster munitions is not included in the dictionary. Lexical unit cluster is found in the munition dictionary article on p. 90, which looks like this: (военное)

mипition боеприпас (b); средства поражения; снаряжение

${ }^{26}$ Glossary of mine action terms, definitions and abbreviations. URL: Available online https://www.mineactionstandards.org/fileadmin/MAS/documents/imas-international-

standards/english/series-

04/IMAS_04.10_Glossary_of_mine_action_terms_definitions_and_abbreviations.pdf.

${ }^{27}$ Ibid.

${ }^{28}$ Палей С. М., Серафина Т. Ф. Словарь по обезвережсиванию взрывных устройств = Dictionary of explosive ordnance disposal: (англо-русский и русско-английский): 5000 терминов, Москва 2010. 
воздуха «внаброс»

air-scatterable $\sim$ б боеприпасы для дистаничионного минирования $c$

area denial artillery $\sim$ артиллерийский боеприпас кассетного снаряжения

cluster $\sim$ кассетное снаряжение

dispenser $\sim$ sкассетные боеприпасы

dud неразорвавшийся боеприпас

mortar $\sim$ sминомётные боеприпасы

pursuit deterrent $\sim$ защитное вооружение.

This cluster dictionary structure is appropriate for people with philological education at a time when ordinary demining specialists who do not have sufficient English language will not be able to use the source.

\section{CONCLUSIONS}

Thus, it can be postulated that the terminology of humanitarian demining is an indispensable object of philological terminological exploration. The practical meaning of the such nominations research is beyond doubt, since the process of humanitarian demining in Ukraine just begins, which creates the demand for translators in this field. The need for the English-Ukrainian dictionary of explosive devices not only exists, but can also be considered as a priority for Ukrainian terminological study.

\section{SUMMARY}

The article deals with the specialised communication that is realised with the help of specialised languages which can be defined as linguistic tools used for specialised communication between experts, in specialised contexts for the transfer of specialised knowledge. The choice of the linguistic tools is determined by the form of the communication and the level of the specialisation. Within specialised language, oral and written communication as well as official and non-official specialised language usage can be distinguished. In our classification the specialised texts are seen as the main tool of the written form of the official specialised communication, while jargon was considered as the primary form of the oral non-official specialised communication.

In the absence of active military actions in eastern Ukraine for more than a year, one of the main threats to the lives of both Ukrainian servicemen and Ukrainians living in the zone of ATO became mines, unbreakable shells and remnants of explosive devices, which are practically sown on the territory of Donbass. On October 2, 2015, in Paris, an agreement was reached between the leaders of Ukraine, France and Germany, that Paris and Berlin would assist Ukraine in demining of the territory under the aegis of the OSCE. 
Ukrainian language policy is realized in the need to create both monolingual Ukrainian terminological dictionaries and glossaries as well as bilingual lexicographic sources. Unfortunately, there is no dictionary published in Ukrainian in the field of demining.

\section{REFERENCES}

1. Глосарій термінів, визначень і скорочень з питань протимінної діяльності.

URL: Available

online https://www.mineactionstandards.org/fileadmin/MAS/documents/imasinternational-standards/Ukrainian/IMAS_04.10_ukr.pdf.

2. Мартинюк Віталій, Зварич Олена. Гуманітарне розмінування Донбасу - довгий шлях до безпеки людей. УНЦПД, 22 рік видання, №30/753, 30 квітня 2016. Available online URL: http://www.ucipr.org.ua/ index.php?option=com_content $\&$ view=article\&id=91:guman-tarne-rozmnuvannya-donbasu-dovgiy-shlyah-do-bezpeki-lyudey\&catid=8\&lang= ua\&Itemid=201.

3. Палей С. М., Серафина Т. Ф. Словарь по обезвереживанию взрывных устройств = Dictionary of explosive ordnance disposal: (англорусский и русско-английский): 5000 терминов, Москва 2010.

4. Словник української мови в 11 томах / за ред. І. К. Білодіда, Київ 1970-1980.

5. ABBYY Lingvo x5. URL: Available online https://www.abbyy.com/ ru-ru/support/lingvox5_sr/.

6. Arntz R. Fachbezogene Mehrsprachigkeit in Recht und Technik, London/New York P. 43-63 2001.

7. Borja A., Garcia I., Montalt V. Research Methodology in Specialized Genres for Translation Purposes, in: Mason, Ian (ed.): The Interpreter and Translator Trainer 3 (1), Special Issue: Training for Doctoral Research, Manchester P. 57-77 2009.

8. Brekke M. Linguistic Aspects of the Translation of Scientific and Technical Texts, in: Kittel, Harald; Frank, Armin P.; Greiner, Norbert; Hermans, Theo; Koller, Werner; Lambert, José; Paul, Fritz (eds); in association with House, Juliane; Schultze, Brigitte: Übersetzung. Translation. Traduction. Ein internationales Handbuch zur Übersetzungsforschung. Volume 1. Berlin/New York P. 619-635 2004.

9. Byrne J. Scientific and Technical Translation Explained. A Nuts and Bolts Guide for Beginners, Manchester 2012.

10. Byrne J. Technical Translation. Usability Strategies for Translating Technical Documentation, Dordrecht 2006.

11. Encyclopedia Britannica. URL: Available online https://www.britannica.com/search?query=mine. 
12. Felber H. Terminology manual. Available online http: //unesdoc.unesco.org/Ulis/cgi- bin/ulis.pl?catno=62033, Paris 1984.

13. Glossary of Military Terms and Slang from the Vietnam War. URL: Available online http://www2.iath.virginia.edu/sixties/HTML_docs/ Resources/Glossary/Sixties_Term_Gloss_A_C.html.

14. Glossary of mine action terms, definitions and abbreviations. URL: Available online https://www.mineactionstandards.org/fileadmin/ MAS/documents/imas-international-standards/english/series-

04/IMAS_04.10_Glossary_of_mine_action_terms_definitions_and_abbreviati ons.pdf.

15. Lakoff G. Women, Fire, and Dangerous Things. What Categories Reveal About the Mind, Chicago 1987.

16. Mounin G. Die Übersetzung. Geschichte, Theorie, Anwendung, München 1967.

17. Newmark P. Approaches to Translation, London 1981.

18. Olohan M. Scientific and Technical Translation, in: Baker, Mona; Saldanha, Gabriela (eds): Routledge Encyclopedia of Translation Studies, London/New York 2009, P. 246-249.

19. Pinchuck I. Scientific and Technical Translation, London 1977.

20. Salama-Carr M. The Translation of Scientific Discourse Constraints and Challenges, in: Krein-Kühle, Monika; Wienen, Ursula; Krüger, Ralph (eds): Kölner Konferenz zur Fachtextübersetzung (2010), Frankfurt/ M. P. 19-32. 2013.

\section{Information about the author:} Palchevska O. S.,

Ph.D., Associate Professor at the Department of Foreign Languages and Translation Studies,

Lviv State University of Life Safety

35, Kleparivska str., Lviv, 79007, Ukraine 